\title{
Oleanonic acid from Lippia lupulina (Verbenaceae) shows strong in vitro antileishmanial and antitrypanosomal activity
}

\author{
Cristiano S. FUNARI'*, Letícia de ALMEIDA² ${ }^{2}$, Thais G. PASSALACQUA² , Isabel MARTINEZ² \\ Daniela L. AMBRÓSIO ${ }^{2}$, Regina Maria B. CICARELLI ${ }^{2}$, Dulce Helena S. SILVA ${ }^{3}$, Márcia A. S. GRAMINHA² \\ ${ }^{1}$ São Paulo State University (UNESP), College of Agricultural Sciences, CP 237, CEP 18610-307, Botucatu, SP, Brazil \\ ${ }^{2}$ São Paulo State University (UNESP), School of Pharmaceutical Sciences, CEP 14801-902, Araraquara, SP, Brazil \\ ${ }^{3}$ São Paulo State University (UNESP), Institute of Chemistry, CP 355, CEP 14801-970, Araraquara, SP, Brazil \\ *Corresponding author: cristianofunari@fca.unesp.br, csfunari@gmail.com
}

\section{ABSTRACT}

Leishmaniasis and Chagas disease affect millions of people in tropical and subtropical regions. Drugs used currently to treat such diseases often present undesirable side effects and low efficiency. The aim of this work was to identify extracts and isolated compounds from the genus Lippia with leishmanicidal and trypanocidal activity. Fifteen extracts from different plant parts of Lippia species with partially known chemical compositions, four partition fractions, six compounds and a mixture of four interconverting flavanones previously isolated from Lippia salviaefolia and Lippia lupulina were assayed in vitro towards epimastigote forms of Trypanosoma cruzi and promastigote forms of Leishmania amazonensis. The root extract of L. lupulina had potent activity against T. cruzi and L. amazonensis ( $\mathrm{IC}_{50}$ of 20.0 and $54.5 \mu \mathrm{g} \mathrm{mL} \mathrm{mL}^{-1}$, respectively). The triterpenoid oleanonic acid showed the strongest activity against these protozoans ( $\mathrm{IC}_{50}$ of 18.5 and $29.9 \mu \mathrm{M}$, respectively). Our results indicate that Lippia plants and their derivatives deserve further investigation in the search for new antiprotozoal drugs, particularly for the treatment of leishmaniasis and Chagas disease.

KEYWORDS: Leishmanicidal, trypanocidal, triterpenoids, flavonoids, T. cruzi

\section{Ácido oleanônico isolado de Lippia lupulina (Verbenaceae) apresenta potentes atividades leishmanicida e tripanocida}

Leishmaniose e doença de Chagas afetam milhôes de pessoas em regiōes tropicais e subtropicais. As drogas atualmente usadas para tratar estas doenças frequentemente apresentam efeitos colaterais indesejáveis e baixa eficiência. Este trabalho teve como objetivo encontrar extratos, fraçóes e compostos isolados de espécies do gênero Lippia com atividades leishmanicida e tripanocida. Quinze extratos de diferentes partes de plantas do gênero Lippia, com composições químicas parcialmente conhecidas, quatro fraçôes de partição, seis substâncias e uma mistura de quatro flavanonas interconversíveis isolados de Lippia salviaefolia e Lippia lupulina foram testados, in vitro, frente a formas epimastigotas de Trypanosoma cruzi e promastigotas de Leishmania amazonensis. $\mathrm{O}$ extrato etanólico das raízes de L. lupulina apresentou atividade potente contra T. cruzi e L. amazonensis $\left(\mathrm{IC}_{50}\right.$ de 20,0 e 54,5 $\mu \mathrm{g} \mathrm{mL} \mathrm{mL}^{-1}$, respectivamente), enquanto que o ácido oleanônico mostrou as atividades mais fortes contra estes protozoários, com $\mathrm{IC}_{50}$ de 18,5 e 29,9 $\mu \mathrm{M}$, respectivamente. Estes resultados indicam que espécies do gênero Lippia e seus derivados merecem investigaçóes adicionais na busca por novas terapias antiprotozoárias, especialmente para o tratamento de leishmaniose e doença de Chagas.

PALAVRAS-CHAVE: leishmanicida, tripanocida, ácido oleanônico, flavonoides, T. cruzi 


\section{INTRODUCTION}

Leishmaniasis and Chagas disease are classified as neglected diseases (Morel 2003). They occur in tropical and subtropical regions causing substantial morbidity among poor people living in low socioeconomic environment. These diseases have not been a priority in the search for drug development because of limited financial incentives from the private sector (Kappagoda and Ioannidis 2012).

Leishmaniasis is caused by the parasitic protozoa of the genus Leishmania. It affects about 12 million people worldwide in 98 countries (Barrett and Croft 2012; WHO 2016). This disease is characterized by high diversity and complexity; it is caused by more than 20 species of the genus Leishmania and is transmitted to humans by about 30 different species of sandflies (Chappuis et al. 2007). In most cases, leishmaniasis is divided into three primary clinical forms: cutaneous leishmaniasis, mucocutaneous leishmaniasis, and visceral leishmaniasis or Kala-azar (Van Assche et al. 2011). One of the etiologic agents of cutaneous leishmaniasis in South American countries is Leishmania amazonensis, a member of the Leishmania mexicana complex. Leishmania amazonensis can cause mild cutaneous leishmaniasis and diffuse cutaneous leishmaniasis (Soong et al. 2012). The leishmaniasis treatment includes pentavalent antimonials (Pentostam $^{\circledast}$ and Glucantime ${ }^{\odot}$ ), the polyene antibiotic amphotericin B (including the lipid preparation Ambisome ${ }^{\circledast}$ ) and pentamidine. However, such drugs are costly, show undesirable side effects and resistant strains have emerged (Croft and Olliaro 2011; Tempone et al. 2011) which reinforces the need for novel therapeutic agents.

Chagas disease is caused by Trypanosoma cruzi, an intracellular parasite commonly transmitted to humans and other mammals by a Triatominae (Reduviidae). The disease may also be spread through blood transfusion, vertical transmission, and less frequently, through organ transplantation (Márquez et al. 2013). The World Health Organization (WHO) estimates that approximately 10 million individuals are currently infected with T. cruzi with potential for developing cardiac or gut pathology associated with chronic Chagas disease (Afonso et al. 2012). The two available drugs for treatment of Chagas disease, nifurtimox and benznidazole, have potential toxic side effects and variable efficacy. These drugs are unable to eradicate the infection during the chronic phase when most patients are diagnosed, which consequently contributes to their low prescription and rate of use (Coura 2009).

Based on these considerations, the search for new therapeutic agents for the treatment of leishmaniasis and Chagas disease is urgently needed. From 1981 to 2010, among the 1355 new chemical entities approved by the Food and Drug Administration (USA), only 29\% were synthetic in origin, thus demonstrating the influence of "other than formal synthetics" on drug discovery and approval (Newman and Cragg 2012). Brazilian flora might also be regarded as one important source of new active compounds against parasitic protozoa (Funari and Ferro 2005, Mishra et al. 2009). The aim of this work was to identify extracts and isolated compounds from Lippia spp. with leishmanicidal and trypanocidal activity.

\section{MATERIALS AND METHODS}

\section{Plant material}

Parts of Lippia salviaefolia Cham. (Verbenaceae) and Lippia velutina Schauer were collected on April 1 $1^{\text {st }}, 2006$ and February $12^{\text {th }}, 2006$, respectively, in Mogi-Guaçu city (Fazenda Campininha), São Paulo State, Brazil. Voucher specimens were deposited in "Herbarium Maria Eneida P. Kaufmann" of "Instituto Botânico de São Paulo", under the subscriptions Lima 90 and Brumati TI73, respectively. Parts of Lippia balansae Briq. and Lippia lasiocalycina Cham. were collected on March $7^{\text {th }}, 2008$ and May 15 $5^{\text {th }}, 2008$ in Santa Cruz do Rio Pardo (Rodovia Castelo Branco, km 03) and Pratânia cities, respectively, São Paulo State, Brazil. Voucher specimens were deposited in the "Herbarium Coleção Botânica da Floresta Estadual de Assis", under subscriptions FEA 402, FEA 3556, respectively. Parts of Lippia sidoides Cham. and Lippia lupulina Cham. were collected on January $19^{\text {th }}, 2009$ and January 22 ${ }^{\text {th }}, 2009$, respectively, in Iaras city, São Paulo State, Brazil. Voucher specimens were also deposited in the "Herbarium Coleção Botânica da Floresta Estadual de Assis", under subscriptions FEA 3639 and FEA 3638, respectively (Funari et al. 2012a).

\section{In vitro assay for trypanocidal activity}

Epimastigote forms of $T$. cruzi Y strain were grown axenically at $28^{\circ} \mathrm{C}$ in Liver-Infusion Tryptose (LIT) medium supplemented with $10 \%(\mathrm{v} / \mathrm{v})$ heat-inactivated fetal calf serum (FCS). LIT medium was prepared by mixing $10 \mathrm{mg}$ $\mathrm{mL}^{-1}$ hemin (bovine, type I) $(1 \mathrm{~mL})$ with a solution containing $\mathrm{NaCl}$ (4.0 g), $\mathrm{KCl}(0.4 \mathrm{~g}), \mathrm{Na}_{2} \mathrm{PO}_{4}(8.0 \mathrm{~g})$, glucose (2.0 g), liver infusion broth $(5.0 \mathrm{~g})$, and tryptose $(5.0 \mathrm{~g})$ at $\mathrm{pH} 7.0(900$ $\mathrm{mL}$ ). The epimastigotes were harvested during the exponential growth phase (7-day-old culture forms). An aliquot of 50 $\mu \mathrm{L}$ of a $1 \times 10^{7}$ parasites $\mathrm{mL}^{-1}$ suspension was added to each well of a 96 multi-well microplate. Extracts or compounds previously prepared or isolated by our group (Funari et al. 2011; Funari et al. 2012a; Funari et al. 2012b) were dissolved in dimethylsulfoxide (DMSO) and further added to each well to reach final concentrations from 1 to $100 \mu \mathrm{g} \mathrm{mL} \mathrm{m}^{-1}$. Aliquots of $50 \mu \mathrm{L}$ of LIT medium, with and without parasites, were added to the control wells in the absence of test compounds. Microplates were incubated at $28{ }^{\circ} \mathrm{C}$ for $72 \mathrm{~h}$. After this period, an aliquot of $10 \mu \mathrm{L}$ of a 3-(4,5-dimethylthiazol-2- 
yl)-2,5-diphenyltetrazolium bromide-phenazine methosulfate (MTT-PMS) solution $\left(2.5 \mathrm{mg} \mathrm{mL}^{-1}\right)$ was added to each well, and the plates were incubated in the dark, at $28^{\circ} \mathrm{C}$, for $75 \mathrm{~min}$. Subsequently, $100 \mu \mathrm{L}$ of a solution of $10 \%$ sodium dodecyl sulfate (SDS) were added to each well and maintained at room temperature, in the dark, for $30 \mathrm{~min}$. Absorbance of the solutions contained in the wells were read at $595 \mathrm{~nm}$ (Readwell Touch, Robonik PVT LTD, Thane, India). All the assays were performed in triplicate. Test samples concentrations corresponding to $50 \%$ of parasite growth inhibition $\left(\mathrm{IC}_{50}\right)$ were determined from non-linear regression (Muelas-Serrano et al. 2000; Santos et al. 2012).

\section{In vitro assay for leishmanicidal activity}

Promastigote forms of L. amazonensis (MPRO/BR/1972/ M1841-LV-79) were grown at $28{ }^{\circ} \mathrm{C}$ in LIT medium supplemented with $10 \%(\mathrm{v} / \mathrm{v})$ heat-inactivated FCS. The parasites were harvested at the end of the exponential growth phase (4-day-old culture forms). An aliquot of $97 \mu \mathrm{L}$ of a 8 $\times 10^{6}$ parasites $\mathrm{mL}^{-1}$ suspension was added to each well of a 96 multi-well microplate. Extracts or compounds previously prepared or isolated by our group (Funari et al. 2011; Funari et al. 2012a; Funari et al. 2012b) were dissolved in DMSO and an aliquot of $3 \mu \mathrm{L}$ was further added to each well to reach final concentrations from 1.6 to $100 \mu \mathrm{g} \mathrm{mL}^{-1}$. Microplates were incubated at $28^{\circ} \mathrm{C}$ for $72 \mathrm{~h}$. After this period, a $10 \mu \mathrm{L}$ aliquot of $2.5 \mathrm{mg} \mathrm{mL}^{-1}$ MTT-PMS solution was added to each well, and the plates were further incubated for $75 \mathrm{~min}$, in the dark, at $28^{\circ} \mathrm{C}$. Subsequently, $100 \mu \mathrm{L}$ of $10 \%$ SDS were added to each well and maintained at room temperature, in the dark, for $30 \mathrm{~min}$. Absorbances of the solutions in the wells were read at $490 \mathrm{~nm}$ (Readwell Touch, Robonik PVT LTD, Thane, India). Pentamidine isethionate (Sigma-Aldrich, St Louis, MO, USA) was used as reference drug. The assays were carried out in triplicate. Test samples concentrations corresponding to $50 \%$ of parasite growth inhibition $\left(\mathrm{IC}_{50}\right)$ were determined from non-linear regression (Muelas-Serrano et al. 2000; Santos et al. 2012).

\section{RESULTS}

Among the fifteen ethanol extracts tested in this work against epimastigote forms of $T$. cruzi, the extract of $L$. lupulina roots was the most active with $\mathrm{IC}_{50} 20.0 \mu \mathrm{g} \mathrm{mL} \mathrm{m}^{-1}$. An ethyl acetate fraction (FAc) obtained from the extract of L. salviaefolia leaves was the second most effective against this protozoa $\left(\mathrm{IC}_{50} 71.9 \mu \mathrm{g} \mathrm{mL}-1\right.$ ), followed by the extract of $L$. velutina leaves and an extract of $L$. lupulina stems and leaves combined (both with $\mathrm{IC}_{50} 85.5 \mu \mathrm{g} \mathrm{mL} \mathrm{L}^{-1}$ ). Regarding activity against promastigote forms of $L$. amazonensis, the extract of L. lupulina roots was again the most active with $\mathrm{IC}_{50} 54.5$ $\mu \mathrm{g} \mathrm{mL} \mathrm{m}^{-1}$. It was followed by the extract of L. lupulina leaves $\left(\mathrm{IC}_{50} 95.4 \mu \mathrm{g} \mathrm{mL} \mathrm{m}^{-1}\right)$ and by FAc $\left(\mathrm{IC}_{50} 134 \mu \mathrm{g} \mathrm{mL}^{-1}\right)$. The results for all extracts are summarized in Table 1 . Among the pure compounds, a triterpenoid (oleanonic acid, 1; Figure 1) showed best inhibitory activity against both $T$. cruzi and L. amazonensis, with $\mathrm{IC}_{50} 8.4$ and $13.6 \mu \mathrm{g} \mathrm{mL} \mathrm{m}^{-1}$, respectively. The results obtained for pure compounds are summarized in Table 2.

Table 1. Trypanocidal and leishmanicidal activity of fifteen ethanol extracts from Lippia species and of four partition fractions obtained from the ethanol extract of leaves of Lippia salviaefolia (EELLsal). Benznidazole and pentamidine were used as reference drugs for Trypanosoma cruzi and Leishmania amazonensis, respectively.

\begin{tabular}{lcc}
\hline \multirow{2}{*}{ Sample } & \multicolumn{2}{c}{$\mathrm{IC}_{50}$ values $\left(\mu \mathrm{g} \mathrm{mL}^{-1}\right)$} \\
\cline { 2 - 3 } & T. cruzi & L. amazonensis \\
\hline L. balansae Flowers & 147.8 & n.t. \\
L. balansae Leaves & 145.8 & n.t. \\
L. balansae Stems & 374.8 & n.t. \\
L. lasiocalycina Leaves and Stems & $>500$ & n.t. \\
L. sidoides Leaves & 122.3 & 136.1 \\
\hline L. sidoides Stems & $>500$ & 430.0 \\
\hline L. sidoides Roots & 206.1 & Inactive \\
\hline L. Iupulina Flowers & $>500$ & 180.0 \\
\hline L. Iupulina Leaves & $>500$ & 95.4 \\
\hline L. Iupulina Stems & 85.5 & 390.1 \\
\hline L. Iupulina Roots & 20.0 & 54.5 \\
\hline L. velutina Stems & $>500$ & Inactive \\
L. velutina Leaves & 85.5 & n.t. \\
L. salviaefolia Stems & $>500$ & Inactive \\
\hline L. salviaefolia Leaves & 150.9 & 173.3 \\
\hline Hexane fraction of EELLsal & 500 & 269.9 \\
\hline Ethyl acetate fraction of EELLsal & 71.9 & 134.7 \\
\hline n-Butanol fraction of EELLsal & 337.9 & Inactive \\
\hline Aqueous fraction of EELLsal & $>500$ & Inactive \\
Reference drug & 9.7 & 4.0 \\
\hline
\end{tabular}

n.t. not tested.

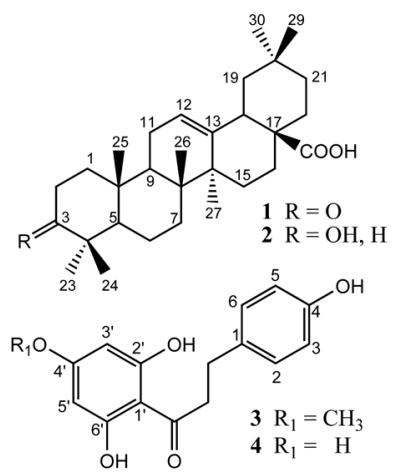<smiles>[R]C1=C([R9])C([R3])C2OC(c3ccc(O)c([R])c3)C([R])C(=O)C2=C1O</smiles>
$\begin{array}{lllll}\mathrm{R}_{1} & \mathrm{R}_{2} & \mathrm{R}_{3} & \mathrm{R}_{4} & \mathrm{R}_{5}\end{array}$ $\begin{array}{llllll}5 & \mathrm{H} & \mathrm{CH}_{3} & \mathrm{H} & \mathrm{H} & \mathrm{H} \\ 6 & \mathrm{H} & \mathrm{H} & \mathrm{H} & \mathrm{H} & \mathrm{H}\end{array}$ $\begin{array}{llllll}6 & \mathrm{H} & \mathrm{H} & \mathrm{H} & \mathrm{H} & \mathrm{H}\end{array}$ $7 \mathbf{a} / 7 \mathbf{b} \quad \mathrm{OH}$ Glu $\mathrm{H} \quad \mathrm{H} \quad \mathrm{OH}$ $\mathbf{8 a} / \mathbf{8 b}$ H $\quad$ Glu $\mathrm{OH} \quad \mathrm{H} \quad \mathrm{OH}$

Figure 1. Compounds assayed against Trypanosoma cruzi and Leishmania amazonensis: oleanonic acid (1), oleanolic acid (2), asebogenin (3), phloretin (4), sakuranetin (5), naringenin (6) and the mixture of interconverting flavanones $(2 R)$ - and (2S)-3',4',5,6-tetrahydroxyflavanone-7-0- $\beta$ glucopyranoside (7a/7b); and (2R)- and (2S)-3',4',5,8-tetrahydroxyflavanone7-0- $\beta$-glucopyranoside $(\mathbf{8 a} / \mathbf{8 b})$. 
Table 2. Trypanocidal and leishmanicidal activity of compounds isolated from Lippia species.

\begin{tabular}{lcccc}
\hline \multirow{2}{*}{ Compound } & \multicolumn{2}{c}{ T. cruzi IC $\mathrm{I}_{50}$ values } & \multicolumn{2}{c}{$\begin{array}{c}\text { L. amazonensis } \mathrm{IC}_{50} \\
\text { values }\end{array}$} \\
\cline { 2 - 5 } & $\mu \mathrm{g} \mathrm{mL}^{-1}$ & $\mu \mathrm{M}$ & $\mu \mathrm{g} \mathrm{mL}^{-1}$ & $\mu \mathrm{M}$ \\
\hline Oleanonic acid (1) & 8.4 & 18.5 & 13.6 & 29.9 \\
Oleanolic acid (2) & 58.4 & 128.1 & n.t. & n.t. \\
\hline Asebogenin (3) & 41.3 & 143.4 & 47.5 & 165.0 \\
\hline Phloretin (4) & $>100$ & $>365.0$ & 79.7 & 290.9 \\
\hline Sakuranetin (5) & 47.5 & 166.1 & 39.4 & 137.8 \\
\hline Naringenin (6) & 84.2 & 309.5 & $>100$ & $>367.6$ \\
\hline Mixture (7a/7b/8a/8b) & n.t. & n.t. & $>100$ & $>214.6$ \\
\hline Benznidazole & 9.7 & 37.3 & n.t. & n.t. \\
\hline Pentamidine & n.t. & n.t. & 4.0 & 11.8 \\
\hline
\end{tabular}

'Mixture of interconverting flavanones (2R)- and (2S)-3',4',5,6-tetrahydroxyflavanone7-0- $\beta$-glucopyranoside $(7 \mathbf{a} / 7 \mathbf{b})$; and $(2 R)$ - and (2S)-3, $4^{\prime}, 5,8$-tetrahydroxyflavanone7-0- $\beta$-glucopyranoside $(\mathbf{8 a} / \mathbf{8 b})$,

$7-0-\beta$-glucopy
n.t. not tested.

\section{DISCUSSION}

\section{Trypanocidal activity}

Osorio et al. (2007) tested plant extracts against epimastigote forms of T. cruzi and promastigote forms of L. amazonensis, and proposed that extracts should be classified as highly active $\left(\mathrm{IC}_{50}\right.$ lower than $10 \mu \mathrm{g} \mathrm{mL} \mathrm{mL}^{-1}$ ), active $\left(\mathrm{IC}_{50}\right.$ between 10 and $50 \mu \mathrm{g}$ $\left.\mathrm{mL}^{-1}\right)$, moderately active $\left(\mathrm{IC}_{50}\right.$ higher than 50 and lower than $100 \mu \mathrm{g} \mathrm{mL}^{-1}$ ) or non-active ( $\mathrm{IC}_{50}$ higher than or equal to 100 $\left.\mu \mathrm{g} \mathrm{mL} \mathrm{m}^{-1}\right)$. According to such criteria, the extract of L. lupulina roots could be classified as active against T. cruzi $\left(\mathrm{IC}_{50} 20.0 \mu \mathrm{g}\right.$ $\left.\mathrm{mL}^{-1}\right)$. FAc $\left(\mathrm{IC}_{50} 71.9 \mu \mathrm{g} \mathrm{mL}^{-1}\right)$ and the extracts of $L$. velutina leaves and of $L$. lupulina stems and leaves combined might be classified as moderately active (both with $\mathrm{IC}_{50} 85.5 \mu \mathrm{g} \mathrm{mL} \mathrm{m}^{-1}$ ). The remaining extracts (Table 1) should be classified as nonactive (Osorio et al. 2007).

Our findings corroborate previously reported data on trypanocidal activity of Lippia species polar extracts (Abe et al. 2005; Sülsen et al. 2006). Sülsen et al. (2006) reported in vitro activity of an organic and an aqueous extracts obtained from leaves of Lippia integrifolia against epimastigote forms of $T$. cruzi, with 34.5 and $71.2 \%$ inhibition, respectively, at $10 \mu \mathrm{g} \mathrm{mL} \mathrm{m}^{-1}$. On the other hand, Abe et al. (2005) reported in vitro activity of a methanol extract of Lippia dulcis leaves against trypomastigote forms of T. cruzi, with MIC (minimum inhibitory concentration) between 125 and 250 $\mu \mathrm{g} \mathrm{mL} \mathrm{m}^{-1}$. Similar inhibitory activities have been observed in our experiments against epimastigote forms of T. cruzi, with $\mathrm{IC}_{50}$ between 20 and $375 \mu \mathrm{g} \mathrm{mL} \mathrm{m}^{-1}$ (Table 1 ).

Among the pure compounds isolated from Lippia species, the triterpenoid oleanonic acid (1) was the most active compound against both parasites tested in this work (Table 2). It exhibited 2.4-fold more potent trypanocidal activity than that from the original root extract of L. lupulina $\left(\mathrm{IC}_{50} 8.4\right.$ and $20.0 \mu \mathrm{g} \mathrm{mL} \mathrm{m}^{-1}$, respectively). Considering the trypanocidal $\mathrm{IC}_{50}$ values in $\mu \mathrm{M}$, compound $\mathbf{1}$ was 2 -fold more potent than the reference drug benznidazole (Table 2). Oleanonic acid (1) was 6.9-fold more potent against $T$. cruzi than another triterpenoid, oleanolic acid (2) $\left(\mathrm{IC}_{50} 8.4\right.$ and $58.4 \mu \mathrm{g} \mathrm{mL} \mathrm{m}^{-1}$, respectively, Table 2 ). This suggests that a keto group at C-3 might be more important for trypanocidal activity than a hydroxyl group at the same position (Figure 1).

On the other hand, Cunha et al. (2003) reported just the opposite. These authors found a 3.1-fold higher in vitro activity of oleanolic acid (2) against blood trypomastigote forms of T. cruzi $\mathrm{Y}$ strain when compared to oleanonic acid (1), with $\mathrm{IC}_{50} 80.4$ and $294.9 \mu \mathrm{M}$, respectively. Such chemical groups could influence the molecules lipophilicity, interfering with their ability to penetrate through biological membranes and exert its activity. More recently, Ferreira et al. (2010) reported in vitro trypanocidal activity of oleanolic acid (2) against trypomastigote forms of T. cruzi H6 strain (Bolivian strain) with $\mathrm{IC}_{50} 45.2 \mu \mathrm{M}$, which is 2.2 -fold more potent than the trypanocidal activity observed for compound $\mathbf{2}$ when tested against the epimastigote form of T. cruzi (Table 2).

Among the flavonoids, the dihydrochalcone asebogenin (3) and the flavanone sakuranetin (5) ( $\mathrm{IC}_{50} 41.3$ and 47.5 $\mu \mathrm{g} \mathrm{mL} \mathrm{m}^{-1}$, respectively, Table 2 ) exhibited higher trypanocidal activity than their original source sample $\left(\mathrm{FAc}, \mathrm{IC}_{50} 71.9 \mu \mathrm{g}\right.$ $\mathrm{mL}^{-1}$, Table 1). On the other hand, the flavanone naringenin (6) $\left(\mathrm{IC}_{50} 84.2 \mu \mathrm{g} \mathrm{mL} \mathrm{mL}^{-1}\right)$ was slightly less effective than FAc. Compounds 3, 5 and $\mathbf{6}$ were also detected in the remaining active extracts against $T$. cruzi which presented similar chromatographic profiles by HPLC-PDA and UHPLCPDA-TOF-MS experiments (Funari et al. 2012a, Funari et al. 2012b). Therefore, these findings suggest that such compounds might be partially associated to the trypanocidal activity of the crude extracts and FAc.

According to Ribeiro et al. (1997), sakuranetin (5) isolated from leaves of Trixis vauthieri L. killed 100\% of trypomastigote forms of T. cruzi Y strain in vitro, at $100 \mu \mathrm{g} \mathrm{mL} \mathrm{m}^{-1}$. In another report, this flavanone isolated from Baccharis retusa showed in vitro activity against $T$. cruzi trypomastigotes $\left(\mathrm{IC}_{50} 20.2 \mu \mathrm{g}\right.$ $\mathrm{mL}^{-1}$ ) (Grecco et al. 2012). Similar results were observed for sakuranetin (5) in our experiments against epimastigote forms of T. cruzi Y strain ( $\mathrm{IC}_{50} 47.5 \mu \mathrm{g} \mathrm{mL} \mathrm{m}^{-1}$, Table 2).

Although the dihydrochalcone phloretin (4) did not show detectable trypanocidal activity in our work $\left(\mathrm{IC}_{50}\right.$ higher than $365 \mu \mathrm{M}$, Table 2), it has been described to influence the glucose metabolism of T. cruzi, T. brucei, and T. rangeli (Bakker et al. 1999; Einicker-Lamas et al. 2000; Miletti et al. 2006). 


\section{Leishmanicidal activity}

The extract of L. lupulina roots and the extract of $L$. lupulina leaves might be classified (Osorio et al. 2007) as moderately active against $L$. amazonensis $\left(\mathrm{IC}_{50} 54.5\right.$ and $95.4 \mu \mathrm{g} \mathrm{mL} \mathrm{L}^{-1}$, respectively). All the remaining extracts should be considered non-active against this protozoan, since they exhibited $\mathrm{IC}_{50}$ higher than $100 \mu \mathrm{g} \mathrm{mL}^{-1}$ (Table 1).

Oleanonic acid (1) proved to be the most active pure compound isolated from Lippia spp. assayed in this work $\left(\mathrm{IC}_{50}\right.$ $13.6 \mu \mathrm{g} \mathrm{mL}^{-1}$, Table 2). It was 4 -fold more potent than the extract of $L$. lupulina roots, which afforded compound $\mathbf{1}$ in a previous study (Funari et al. 2012a). Considering the leishmanicidal $\mathrm{IC}_{50}$ values in $\mu \mathrm{M}$, oleanonic acid was 2.5 -fold less potent than pentamidine (Table 2). On the other hand, Torres-Santos et al. (2004) reported 11-fold higher activity of oleanonic acid (1) isolated from leaves of Pourouma guianensis against promastigote forms of L. amazonensis $\left(\mathrm{IC}_{50} 10.0 \mu \mathrm{g} \mathrm{mL} \mathrm{m}^{-1}\right)$.

The flavonoids sakuranetin (5), asebogenin (3) and phloretin (4) exhibited higher leishmanicidal activities $\left(\mathrm{IC}_{50}\right.$ $39.4,47.5$ and $79.5 \mu \mathrm{g} \mathrm{mL}^{-1}$, respectively) than their original source sample FAc $\left(\mathrm{IC}_{50} 134.7 \mu \mathrm{g} \mathrm{mL}{ }^{-1}\right)$. It is noteworthy that such flavonoids were previously detected in the ethanol extract from $L$. sidoides leaves and might therefore be related to its leishmanicidal activity (Funari et al. 2012a).

Grecco et al. (2012) reported $\mathrm{IC}_{50} 51.9 \mu \mathrm{g} \mathrm{mL} \mathrm{m}^{-1}$ for sakuranetin (5) isolated from Baccharis retusa against promastigotes of $L$. amazonensis, which is similar to the results from our experiments against the same type of protozoa (Table 2). Asebogenin (3) isolated from an extract of Piper elongatum aerial parts was described by Hermoso et al. (2003) as more active against promastigote forms of $L$. braziliensis, L. tropica and L. infantum $\left(\mathrm{IC}_{50} 28.5,3.8\right.$ and $6.3 \mu \mathrm{g} \mathrm{mL} \mathrm{L}^{-1}$, respectively) than the observed inhibition against $L$. amazonensis promastigotes $\left(\mathrm{IC}_{50} 47.5 \mu \mathrm{g} \mathrm{mL} \mathrm{g}^{-1}\right.$, Table 2$)$ in our experiments. The leishmanicidal activity observed for phloretin (4) might be related to its influence on the glucose metabolism of $L$. amazonensis, since it was previously described to affect the glucose metabolism in L. mexicana (Burchmore and Hart 1995) and L. donovani (Ter Kuile and Opperdoes 1993).

\section{CONCLUSIONS}

The results presented in this work suggest that Lippia genus and its chemical constituents deserve further investigation in the search for novel antiprotozoal drugs. Special attention should be given to L. lupulina roots, since its ethanol extract exhibited the strongest trypanocidal and leishmanicidal activity among all extracts assayed in this work. Oleanonic acid also deserves further investigation since it showed leishmanicidal activity similar to that observed for the antileishmanial compound pentamidine, and trypanocidal activity higher than benznidazole, the only anti-Chagas therapeutic agent currently in medical use.

\section{ACKNOWLEDGEMENTS}

The authors thank São Paulo Research Foundation (FAPESP) for fellowship (\#06/55162-1) and research funding (\#04/07932-7); Brazilian National Council for Scientific and Technological Development (CNPq) for financial support (grant 453928/2014-5); CNPq and Coordination for the Improvement of Higher Education Personnel (CAPES) for fellowships (to TGP, RMBC and DHSS); and Dr Maria Inês Cordeiro and Dr Giselda Durigan for botanical identifications.

\section{REFERENCES}

Abe, F.; Nagafuji, S.; Okawa, M.; Kinjo, J.; Akahane, H.; Ogura, T.; Martinez-Alfaro, M.A.; Reyes-Chilpa, R. 2005. Trypanocidal constituents in plants 5. Evaluation of some Mexican plants for their trypanocidal activity and active constituents in the seeds of Persea americana. Biological and Pharmaceutical Bulletin, 28: 1314-1317.

Afonso, A.M.; Ebell, M.H.; Tarleton, R.L. 2012. A systematic review of high quality diagnostic tests for Chagas disease. Plos Neglected Tropical Diseases, 6: e1881.

Bakker, B.M.; Walsh, M.C.; Ter Kuile, B.H.; Mensonides, F.I.C.; Michels, P.A.M.; Opperdoes, F.R.; Westerhoff, H.V. 1999. Contribution of glucose transport to the control of the glycolytic flux in Trypanosoma brucei. Proceedings of the National Academy of Sciences, 96: 10098-10103.

Barrett, M.P.; Croft, S.L. 2012. Management of trypanosomiasis and leishmaniasis. British Medical Bulletin, 104: 175-96.

Burchmore, R.J.S.; Hart, D.T. 1995. Glucose transport in amastigote and promastigote forms of Leishmania mexicana mexicana. Molecular and Biochemical Parasitology, 74: 77-86.

Chappuis, F.; Sundar, S.; Hailu, A.; Hashim, G.; Rijal, S.; Peeling, R.W.; Alvar, J.; Boelaert, M. 2007. Visceral leishmaniasis: what are the needs for diagnosis, treatment and control? Nature Reviews Microbiology, 5: 873-882.

Coura, J.R. 2009. Present situation and new strategies for Chagas disease chemotherapy - a proposal. Memórias do Instituto Oswaldo Cruz, 104: 549-554.

Croft, S.L.; Olliaro, P. 2011. Leishmaniasis chemotherapy-challenges and opportunities. Clinical Microbiology and Infection, 17: 1478-1483.

Cunha, W.R.; Martins, C.; Ferreira, D.S.; Crotti, A.E.; Lopes, N.P.; Albuquerque, S. 2003. In vitro trypanocidal activity of triterpenoids from Miconia species. Planta Medica, 69: 470-472.

Einicker-Lamas, M.; Almeida, A.C.; Todorov, A.G.; De Castro, S.L.; Caruso-Neves, C.; Oliveira, M.M. 2000. Characterization of the myo-inositol transport system in Trypanosoma cruzi. European Journal of Biochemistry, 267: 2533-2537.

Ferreira, D.S.; Esperandim, V.R.; Toldo, M.P.A.; Saraiva, J.; Cunha, W.R.; Albuquerque, S. 2010. Trypanocidal activity and acute 
toxicity assessment of triterpene acids. Parasitology Research, 106: 985-989.

Funari, C.S.; Ferro, V.O. 2005. Uso ético da biodiversidade brasileira: necessidade e oportunidade. Revista Brasileira de Farmacognosia, 15: 178-182.

Funari, C.S.; Passalacqua, T.S.; Rinaldo, D.; Napolitano, A.; Festa, M.; Capasso, A.; et al. 2011. Interconverting flavanone glucosides and other phenolic compounds in Lippia salviaefolia Cham. ethanol extracts. Phytochemistry, 72: 2052-2061.

Funari, C.S.; Eugster, P.J.; Martel, S.; Carrupt, P.A.; Wolfender, J.L.; Silva, D.H.S. 2012a. High resolution ultra-high pressure liquid chromatography-time-of-flight mass spectrometry dereplication strategy for the metabolite profiling of Brazilian Lippia species. Journal of Chromatography A, 1259: 167-178.

Funari, C.S.; Gullo, F.P.; Napolitano, A.; Carneiro, R.L.; MendesGiannini, M.J.S.; Fusco-Almeida, A.M.; Piacente, S.; Pizza, C.; Silva, D.H.S. 2012b. Chemical and antifungal investigations of six Lippia species (Verbenaceae) from Brazil. Food Chemistry, 135: 2086-2094.

Grecco, S.S.; Reimão, J.Q.; Tempone, A.G.; Sartorelli, P.; Cunha, R.L.O.R.; Romoff, P.; Ferreira, M.J.P; Fávero, O.A.; Lago, J.H.G. 2012. In vitro antileishmanial and antitrypanosomal activities of flavanones from Baccharis retusa DC. (Asteraceae). Experimental Parasitology, 130: 141-145.

Hermoso, A.; Jimenez, I.A.; Mamani, Z.A.; Bazzocchi, I.L.; Pinero, J.E.; Ravelo, A.G.; Valladares, B. 2003. Antileishmanial activities of dihydrochalcones from Piper elongatum and synthetic related compounds. Structural requirements for activity. Bioorganic and Medicinal Chemistry, 11: 3975-3980.

Kappagoda, S.; Ioannidis, J.P. 2012. Neglected tropical diseases: survey and geometry of randomised evidence. BMJ, 345: e6512.

Márquez, E.; Crespo, M.; Mir, M.; Pérez-Sáez; M.J.; Quintana, S.; Barbosa, F.; Pascual, J. 2013. Chagas disease and kidney donation. Nefrologia, 33:128-133.

Miletti, L.C.; Koerich, L.B.; Pacheco, L.K.; Steindel, M.; Stambuk, B.U. 2006. Characterization of D-glucose transport in Trypanosoma rangeli. Parasitology, 133: 721-727.

Mishra, B.B.; Kale, R.R.; Singh, R.K.; Tiwari, V.K. 2009. Alkaloids: future prospective to combat leishmaniasis. Fitoterapia, 80: 81-90.

Morel, C.M. 2003. Neglected diseases: under-funded research and inadequate health interventions - Can we change this reality? Embo Reports, 4: S35-S38.
Muelas-Serrano, S.; Nogal-Ruiz, J.J.; Gómez-Barrio, A. 2000. Setting of a colorimetric method to determine the viability of Trypanosoma cruzi epimastigotes. Parasitology Research, 86: 999-1002.

Newman, D.J.; Cragg, G.M. 2012. Natural products as sources of new drugs over the 30 years from 1981 to 2010. Journal of Natural Products, 75: 311-335.

Osorio, E.; Arango, G.J.; Jiménez, N.; Alzate, F.; Ruiz, G.; Gutiérrez, D.; Paco, M.A.; Giménez, A.; Robledo, S. 2007. Antiprotozoal and cytotoxic activities in vitro of Colombian Annonaceae. Journal of Ethnopharmacology, 111: 630-635.

Ribeiro, A.; Pilo-Veloso, D.; Romanha, A.J.; Zani, C.L. 1997. Trypanocidal flavonoids from Trixis vauthieri. Journal of Natural Products, 60: 836-838.

Santos, V.A.; Regasini, L.O.; Nogueira, C.R.; Passerini, G.D.; Martinez, I.; Bolzani, V.S.; Graminha, M.A.; Cicarelli, R.M.; Furlan, M. 2012. Antiprotozoal sesquiterpene pyridine alkaloids from Maytenus ilicifolia. Journal of Natural Products, 75: 991-995.

Soong, L.; Henard, C.A.; Melby, P.C. 2012. Immunopathogenesis of non-healing American cutaneous leishmaniasis and progressive visceral leishmaniasis. Seminars in Immunopathology, 34: 735-751.

Sülsen, V.; Güida, C.; Coussio, J.; Paveto, C.; Muschietti, L.; Martino, V. 2006. In vitro evaluation of trypanocidal activity in plants used in Argentine traditional medicine. Parasitology Research, 98: 370-374

Tempone, A.G.; De Oliveira, C.M.; Berlinck, R.G.S. 2011. Current approaches to discover marine antileishmanial natural products. Planta Medica, 77: 572-585.

Ter Kuile, B.H.; Opperdoes, F.R. 1993. Uptake and turnover of glucose in Leishmania. Molecular and Biochemical Parasitology, 60: 313-321.

Torres-Santos, E.C.; Lopes, D.; Oliveira, R.R.; Carauta, J.P.P.; Falcao, C.A.B.; Kaplan, M.A.C.; Rossi-Bergmann, B. 2004. Antileishmanial activity of isolated triterpenoids from Pourouma guianensis. Phytomedicine, 11: 114-120.

Van Assche, T.; Deschacht, M.; Luz, R.A.I.; Maes, L.; Cos, P. 2011. Leishmania-macrophage interactions: insights into the redox biology. Free Radical Biology and Medicine, 51: 337-351.

WHO, 2016. Leishmaniasis magnitude of the problem, (www. who.int/leishmaniasis/burden/magnitude/burden_magnitude/ en/). Acessed on 18/02/2016.

Recebido em 28/01/2016

Aceito em 26/04/2016 